\title{
De huisarts vanuit patiëntenperspectief
}

\author{
Margo Trappenburg
}

De Nederlandse huisarts zoals die eruit ziet vanuit patiëntenperspectief is zelden beter getypeerd dan door Sylvia Witteman in een column in de Volkskrant.

'Nederlandse huisartsen werken over het algemeen volgens het principe "óf het gaat vanzelf over, óf je gaat er toch dood aan", een tijd- en geldbesparend adagium waarnaar de meeste mensen zich zonder morren schikken, alvorens dan ook daadwerkelijk vanzelf beter te worden of dood te gaan. Voor alle kwalen die niet onder bovenstaande criteria vallen staat in de wachtkamer trouwens een handig rekje gereed met foldertjes, van Aambeien tot Zwemmerseczeem: de meeste ziekten zijn, als je de opgewekte leuterpraat mag geloven, te genezen door enige lichaamsbeweging, twee ons groente per dag, een glas warme melk voor het slapen gaan of het aantrekken van schone sokken. ${ }^{1}$

Tegenover deze diepe waarheid staan uiteraard tal van uitspraken van patiënten die dankbaar zijn voor de begeleiding en de laagdrempelige medische zorg van hun huisarts. Zelfs diens strenge poortwachterhouding wordt vaak gewaardeerd, als de patiënt zich realiseert dat de huisarts hem heeft behoed voor een dag lang wachten en oncomfortabele onderzoekjes ondergaan in het ziekenhuis.

Ik wil in dit artikel schetsen hoe de patiënt zich heeft ontwikkeld vanaf de jaren vijftig tot nu. Het eerste deel van die geschiedenis is in kaart gebracht door Annemarie Mol en Peter van Lieshout, in hun proefschrift Ziek is het woord niet. Medicalisering, normalisering en de veranderende taal van huisartsgeneeskunde en geestelijke gezondheidszorg 1945 - 1985. ${ }^{2}$ Mol en Van Lieshout beschrijven hoe de invoering van het ziekenfondsbesluit tijdens de Tweede Wereldoorlog, na de oorlog leidde tot overvolle spreekuren. Mensen vonden het prettig dat zij met hun zorgen bij de huisarts terecht konden, zonder dat zij hoefden te tobben over de kosten. De huisartsen van hun kant vonden dit aanvankelijk verschrikkelijk. Mol en Van Lieshout citeren boze artsen die in Medisch Contact laten weten dat slechts 20 tot 30\% van alle patiënten in hun overvolle wachtkamers iets medisch mankeert. De rest is bezig de tijd van de huisarts te verbeuzelen. Huisartsen eind jaren veertig spraken met waardering over remgelden en no-claimkortingen die je zou moeten invoeren om aan dit verwerpelijke gedrag van hun patiënten een einde te maken.

Tien jaar later, aan het eind van de jaren vijftig lag dat helemaal anders. Op de Woudschotenconferentie van 1959 formuleerden huisartsen hun nieuwe ideaal. Zij wilden al die onzekere, ang-

\section{Auteursgegevens}

Margo Trappenburg is bijzonder hoogleraar Patiëntenperspectief aan het Instituut Beleid en Management van de Gezondheidszorg (EUR). stige patiënten met hun ingebeelde kwaaltjes, hun zorgen en hun huwelijksproblemen juist wél op hun spreekuur zien. Het was hun ideaal om al die patiënten te leren kennen, ze wilden op de hoogte zijn van hun gezinssituatie, ze wilden meeleven met hun hoogteen dieptepunten, ze wilden zich niet beperken tot het verstrekken van antibiotica, het verwijzen van patiënten met verdachte symptomen en het bespreken van ingegroeide teennagels. Patiënt en huisarts leken elkaar in dit opzicht te hebben gevonden.

Een ander kenmerk van de patiënt uit de jaren vijftig en zestig was dat hij tamelijk gezeglijk was en in het algemeen afging op het oordeel van zijn huisarts. Tussen patiënt en huisarts bestond een forse opleidingskloof en huisartsen zagen het niet als hun taak die kloof te dichten. Integendeel. Jolanda Dwarswaard analyseerde jaargangen van Huisarts en Wetenschap uit de jaren '50 en vond daarin onder meer het advies om diagnoses niet te vertellen aan de patiënt, tenzij de ziekte tot blijvende invaliditeit zou leiden. Hoewel de huisarts in de beginfase nog wel wat ziekte-inzicht mag geven, maar alleen om te bereiken dat de patiënt meewerkt.

Tegen het eind van de jaren zestig en in de loop van de jaren zeventig begint dit te veranderen. Het idee wint veld dat patiënten eerlijk moeten worden ingelicht over wat hen mankeert en in meer of mindere mate mee zouden moeten denken over hun behandeling. Er komt een democratiseringsbeweging op gang over de hele breedte van de maatschappij: in de politiek, in de kerk, in de kunst en ook in de gezondheidszorg.

$\mathrm{Nu}$ is er één ding dat $\mathrm{u}$ moet beseffen bij het nadenken over de jaren zestig en zeventig en dat is dat deze roep om democratisering in ongeveer alle westerse landen opkwam, maar nergens zo hard en onverbiddelijk toesloeg als in Nederland. Hoe dat kwam is uitgezocht door James Kennedy, hoogleraar geschiedenis aan de VU en auteur van het prachtige boek Nieuw Babylon in aanbouw. ${ }^{3}$ Kennedy, half Amerikaans en half Nederlands, vraagt zich in dat boek af waarom de jaren zestig in Nederland zoveel meer losmaakten dan in Amerika en hij stelt vast dat dit te maken had met de houding van de elites in Nederland. In Amerika boden de elites weerstand aan de nieuwe sociale beweging van de jaren zestig; in Nederland gingen de elites direct overstag en gaven zij onmiddellijk toe aan de nieuwe eisen en verlangens. Provo's werden door bewindslieden uitgenodigd voor overleg in Den Haag en geprezen voor hun bijdrage aan 'de ontwikkeling van de menselijke geest'. Er kwamen experimentele cafés en gesubsidieerde jeugdclubs waar het gebruik en de verkoop van drugs werd gedoogd. Al in 1970 werd de Wet Universitaire Bestuurshervorming aangenomen, die studenten een grote mate van medezeggenschap gaf in universitaire en facultaire raden. Vele geestelijken meenden dat de toekomst van het christelijke geloof moest worden gevonden in waarden als solidariteit en maatschappelijke betrokkenheid. 
Zij zochten aansluiting bij neomarxistische theorievorming en besteedden hun preken aan internationale politieke vraagstukken.

Volgens Kennedy kwam die toegeeflijkheid van de Nederlandse elites voort uit hun idee dat verandering onvermijdelijk was. De Nederlandse elites waren in de ban van zoiets als 'de tijdgeest' of 'de onverbiddelijke komst van het moderne leven.' Zij anticipeerden op veranderingen en pasten hun gedrag alvast aan.

Dit patroon, dat Kennedy aantrof bij de religieuze, politieke en culturele elites, zien we ook terug in de gezondheidszorg. Ook daar werden de wensen en verlangens van de kleine, prille democratiseringsbeweging onmiddellijk opgepakt en overgenomen door de medisch-professionele elite. De antipsychiatriebeweging in de geestelijke gezondheidszorg werd in belangrijke mate gesteund of zelfs gedragen door psychiaters. Menige patiëntenorganisatie is in de jaren zeventig en tachtig opgericht op instigatie van artsen

Mol en Van Lieshout bespreken een van de kritiekpunten van de democratiseringsbeweging in de zorg, namelijk het verschijnsel dat de medicalisering van problemen patiënten afhankelijk zou kunnen maken van hun artsen. Zij concluderen dat medische hulpverleners opvallend snel meegaan met de op hen geuite kritiek. Huisartsen erkennen vrijwel direct dat hun handelen medicaliserend kan werken en patiënten onmondig en afhankelijk kan maken. Zij beschouwen het als hun plicht om dit te vermijden of terug te draaien. Mondigheid, zo schrijven Mol en Van Lieshout, wordt binnen de kortste keren een therapeutisch ideaal. Het was dus in de jaren zestig en zeventig niet zo dat grote massa's patiënten serieus wilden worden genomen, terwijl hun ouderwetse, paternalistische artsen hen graag klein en inschikkelijk wilden houden. Enkele patiënten en enkele wetenschappers en zaakwaarnemers namens die patiënten wezen erop dat patiënten onmondig en afhankelijk gemaakt werden door de gezondheidszorg. Vele artsen, huisartsen in het bijzonder, onderschreven dit punt en gingen er vervolgens toe over hun patiënten op te voeden tot mondigheid. Niet alleen de patiënten die daar om vroegen, maar ook andere patiënten, die hun eigen onmondigheid nog niet als probleem hadden gepercipieerd.

Er ontstaat in de loop van de jaren zeventig en tachtig een nieuw type patiënt: een mondige patiënt, die mee wil praten met de arts en die niet te veel gedokter aan zijn lijf wenst, omdat hij beducht is voor medicalisering en afhankelijkheid. Maar deze patiënt is voor een belangrijk deel gecreëerd en opgevoed door medische professionals, vooral door huisartsen.

Tot zover de geschiedenis. Wat kunnen we nu zeggen over de patiënt in de jaren negentig en aan het begin van de 21 ste eeuw? Daarvoor kunnen we te rade gaan bij het proefschrift van Henk Schers over continuïteit in de huisartsenzorg en bij de onlangs door het NHG uitgezette NIPO-enquête. Op basis daarvan zou ik zeggen dat de patiënt van nu een mengeling is van de patiënt uit de jaren vijftig en zestig en die uit de jaren zeventig en tachtig.

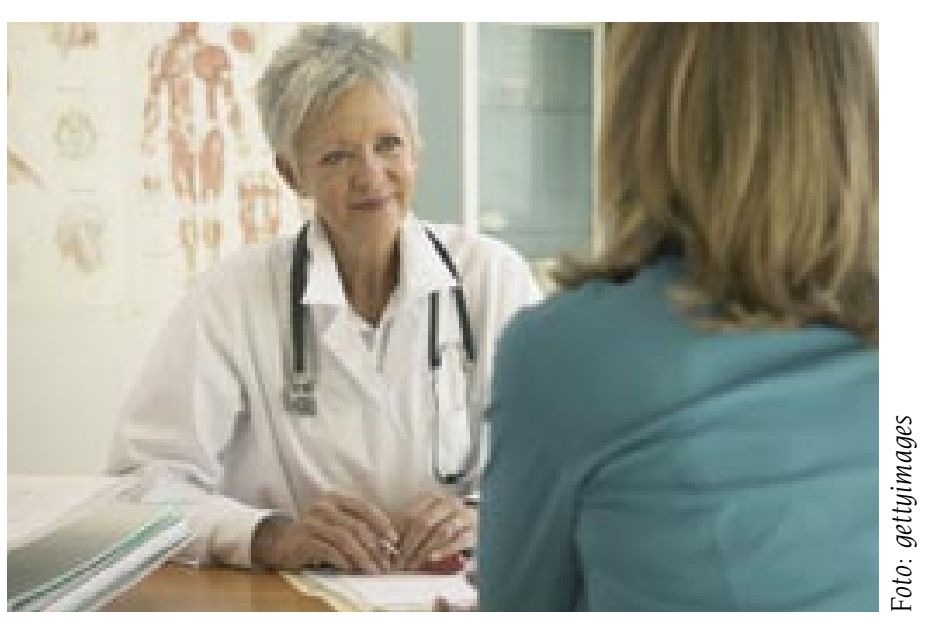

Eerst het jaren-vijftig- en zestigelement. In de NIPO-enquête geven patiënten aan dat zij hun huisarts in vertrouwen zouden nemen bij psychische problemen (86\%), seksuele problemen $(71 \%)$, gokof drankverslaving (66\%), problemen in het gezin (62\%), problemen op het werk (58\%), en bij problemen in de relatie (51\%). ${ }^{4}$ De gemiddelde Nederlander heeft geen problemen met een beetje paternalisme.

Van de gemiddelde patiënt mag de huisarts zelf beginnen over overgewicht, een vermoeden van mishandeling, voeding, roken, onvoldoende beweging, te veel alcohol, stress en veilig vrijen (de percentages in de NIPO-enquête variëren van 70 tot $86 \%$ ). Een meerderheid vindt dat dit ook mag als de patiënt eigenlijk voor iets anders komt.

Schers onderzocht of patiënten het belangrijk vinden om hun eigen huisarts te zien, dan wel genoegen nemen met een willekeurige dokter. Op belangrijke momenten blijkt de patiënt nog steeds graag zijn eigen dokter te zien. Dus niet bij een splinter in het oog, maar wel bij problemen op het werk (76\%), bij plotselinge pijn in de borst (79\%), bij bloed in de ontlasting (82\%), bij gezinsproblemen (87\%) en bij onverhoedse enge buikpijn (91\%). En 96\% wil met de eigen arts overleggen als men een ernstige ziekte onder de leden heeft. Dit omdat - volgens $76 \%$ van de ondervraagden - de eigen huisarts de medische conditie beter kent, en volgens 73\% omdat de huisarts de persoonlijke situatie beter kent. Dit gold voor het overgrote merendeel van de patiënten, ongeacht geslacht, leeftijd, woonplaats of opleidingsniveau.

Schers schrijft: 'What can be learnt from this survey? First, in a changing society with apparent emphasis on turbulence and short-lived interpersonal contacts, most patients within general practice continue to value a personal doctor for serious and emotional problems, regardless of age, sex, place of residence and present circumstances. Secondly, patients appear to value personal continuity because they think that this will be beneficial to their health. Prior knowledge of the medical condition, as well as knowledge of the personal and family background is considered important by patients. ${ }^{5}$

Opvallend is ook dat veel van de door Schers ondervraagde patiënten behoefte bleken te hebben aan aandacht en steun of een bezoekje van hun huisarts op moeilijke of belangrijke momenten 
in hun leven: geboortes, sterfgevallen, ziekenhuisopnames. Maar zij zullen daar niet om vragen.

Patiënten vinden het nog steeds prettig om een eigen huisarts te hebben bij wie zij terechtkunnen, die belangstelling voor hen heeft en met wie zij kunnen praten over hun problemen. Van die huisarts verwachten zij ongevraagde belangstelling, maar van die huisarts accepteren zij ook ongevraagde vermaningen. Zo anders dan in de jaren vijftig en zestig is dat niet.

Patiënten zijn in de jaren negentig en in de $21^{\text {ste }}$ eeuw ook nog steeds zoals zij in de jaren zeventig en tachtig zijn geworden. Regelmatig is vastgesteld dat het aantal consulten bij huisartsen niet extreem groeit, en het aantal als onnodig bestempelde consulten ook niet. Veel patiënten proberen hun medische sores eerst zelf op te lossen. Van de ondervraagden in de NIPO-enquête geeft $88 \%$ aan eerst op internet te zoeken naar oplossingen voor kwaaltjes en pijntjes. Menige patiënt zal de Sylvia Wittemanwijsheid meteen onderschrijven: we hebben geleerd dat we niet naar de huisarts hoeven, omdat het meestal toch vanzelf weer over gaat.

De patiënt van nu is voor een groot deel zoals de patiënt uit de jaren vijftig, zestig, zeventig en tachtig, maar de huisarts van nu is veranderd. De patiënt van nu heeft te maken met parttime werkende huisartsen die niet voortdurend beschikbaar zijn. Hij wordt geconfronteerd met praktijkondersteuners die een deel van het werk van de huisarts over hebben genomen. En als de patiënt van $\mathrm{nu}$ in het weekend iets engs heeft, moet hij naar de huisartsenpost, ook een recente vernieuwing in de zorg. Wat vindt de patiënt van nu daar allemaal van? Over het algemeen worden deze veranderingen door patiënten geaccepteerd. Zij begrijpen dat artsen tegenwoordig hun aandacht verdelen tussen werk en gezin en dat zij opereren in groepspraktijken. De meeste patiënten zijn goed te spreken over de praktijkondersteuner, ruim $70 \%$ is ook wel tevreden over de huisartsenpost.

En hoe ziet de patiënt van de toekomst eruit? Als we mogen afgaan op de informatie vanuit het ministerie van VWS en vanuit de Nederlandse Patiënten Consumenten Federatie is de patiënt van de toekomst een prijs- en kwaliteitsbewuste consument. Die nieuwe patiënt wil geen ongevraagde bemoeienis en zit niet te wachten op sentimentele huisbezoekjes, de nieuwe patiënt wil maatwerk en 'vraaggestuurde' zorg. Hij wil kunnen kiezen voor zorgaanbieders: ziekenhuizen, fysiotherapeuten en huisartsen, op basis van kwaliteitsrankings en consumentvriendelijke websites. Waar de oude patiënt, zeker in de jaren zeventig en tachtig, besefte dat hij zuinig moest zijn met de tijd van de dokter, omdat gezondheidszorg een collectief goed was en de arts nog meer patiënten moest behandelen, daar is de nieuwe patiënt geneigd om zijn eigen zorgpakket samen te stellen en zelf te kiezen voor meer of minder zorg, ongeacht de noden en behoeften van medeburgers. Zorg zal in de toekomst veel minder een publieke voorziening zijn dan nu het geval is, als wij mogen afgaan op de beleidsplannen van het ministerie.

De patiënt van de toekomst is geen project van onderop, hij is een nieuw, lopend opvoedproject van de overheid. In de jaren zeventig en tachtig zijn artsen in het algemeen en huisartsen in het bijzonder direct meegegaan met het toen geproclameerde nieuwe opvoedproject. Zij zijn hun patiënten gaan opvoeden tot mondigheid en zelfstandigheid, zij wilden hen vooral leren niet afhankelijk te worden van de zorg. De medische elite was, net als andere elites in de jaren zestig en zeventig, direct overtuigd van het nut en de noodzaak van vernieuwing, men verzette de bakens en ging patiënten hervormen. De vraag is wat de medische elite in het algemeen en huisartsen in het bijzonder zullen gaan doen met het nieuw geproclameerde opvoedproject. Zullen zij opnieuw proactief gaan meedenken? Zullen zij hun patiënten gaan opvoeden tot kwaliteitsbewuste consumenten, mogelijk opnieuw vanuit het idee dat de tijdgeest dit vraagt en dat ook deze nieuwe verandering onvermijdelijk is?

Dat hoeft niet, zou ik willen benadrukken. Huisartsen kunnen er deze keer ook voor kiezen om niet proactief mee te denken met de patiënt van de toekomst. Als die patiënt van de toekomst er moet komen, laat die patiënt dan maar eigener beweging ontstaan. Niet alle veranderingen zijn een verbetering, niet alle veranderingen zijn onvermijdelijk en niet alle veranderingen behoeven proactieve steun. De patiënt van nu is loyaal aan zijn huisarts. Het zou mooi zijn als de huisarts omgekeerd loyaal zou zijn aan uw patiënt van nu, en de patiënt van de toekomst tot nader order nog maar even in de ijskast zou willen laten zitten.

\section{Literatuur}

1 Sylvia Witteman, Pillen. In: Volkskrant Magazine, 14-10-2006

2 Annemarie Mol, Peter van Lieshout, Ziek is het woord niet. Medicalisering, normalisering en veranderende taal van huisartsgeneeskunde en geestelijke gezondheidszorg 1945 - 1985, Nijmegen: SUN, 1989.

3 James Kennedy. Nieuw Babylon in aanbouw. Nederland in de jaren zestig, Meppel: Boom, 1995.

4 Sietske Lems. De huisarts-patiëntrelatie anno 2006, NHG/TNS Nipo, via www.nhg.artsennet.nl.

5 Henk Schers. Continuity of Care in General Practice: Exploring the balance between personal and informational continuity [Proefschrift]. Radboud Universiteit Nijmegen, 2004. 